\title{
PERBEDAAN PENAFSIRAN DALAM IMPLEMENTASI FATWA NOMOR 23/2002 TENTANG POTONGAN PELUNASAN PADA AKAD MURABAHAH: \\ Studi Perbandingan Lembaga Bank di Kota Malang
}

\author{
Devitha Angesti Tiyasasih, Rachmad Safa'at, \\ Chusen Bisri \\ Magister Kenotariatan Fakultas Hukum Universitas Brawijaya \\ Jalan Veteran, Malang 65145, Indonesia \\ E-mail: devithaangesti@gmail.com
}

\section{Abstract}

Home Financing includes long-term financing that enables the Customer to repay before maturity. This product uses Murabahah principle and based on Fatwa Dewan Syariah Nasional allows for accelerated repayment. Unlike Conventional Banks that impose penalties on accelerated repayment, Bank Syariah provides a deduction for the debt. This study discusses the difference of interpretation between Bank Syariah in implementing Fatwa Number 23/2002 about deduction of payment in Murabahah, sanction of supervision from related institution concerning violation of fatwa and enforcement effort. Research shows that the Bank interprets grammatically with different results, at Bank Muamalat the price discount should not be promised either on the murabah a contract or the internal provisions while the Bank Syariah Mandiri also does not put a clause on the contract but make provisions in the form of internal procedures. The deductions are based on the balance sheet of the Bank and the character of the customer during the period offinancing, and if there is a violation, the National Sharia Board shall not sanction but report to the banking regulator, Bank Indonesia and the Financial Services Authority.

Pembiayaan Pemilikan Rumah termasuk pembiayaan jangka panjang sehingga memungkinkan Nasabah melakukan pelunasan sebelum jatuh tempo. Produk ini banyak menggunakan prinsip Murabahah dan berdasarkan Fatwa Dewan Syariah 
Nasional memungkinkan untuk dilakukan pelunasan dipercepat. Berbeda dengan Bank Konvensional yangmemberikan denda saatpelunasan dipercepat, Bank Syariah memberikan potongan atas hutang. Penelitian ini membahas mengenai adanya perbedaan penafsiran antar Bank Syariah dalam mengimplementasikan Fatwa Nomor 23/2002 tentangpotongan pelunasan dalam Murabahah, sanksipengawasan dari lembaga terkait mengenai pelanggaran fatwa serta upaya penegakan. Penelitian menunjukkan bahwa Bank menafsirkan secara gramatikal dengan hasil berbeda, pada Bank Muamalat potongan harga sama sekali tidak boleh diperjanjikan baik pada akad murabahah maupun ketentuan internal sedangkan Bank Syariah Mandiri juga tidak meletakkan klausula pada akad tapi membuat ketentuan dalam bentuk prosedur internal. Pemberian potongan didasarkan pada keadaan neraca Bank dan karakter nasabah selama masa pembiayaan, dan jika ada pelanggaran maka Dewan Syariah Nasional tidak memberikan sanksi melainkan melakukan pelaporan kepada regulator perbankan yaitu Bank Indonesia dan Otoritas Jasa Keuangan.

Keywords: Islamic Bank, Murabaha, Discount, Early Payment

\section{Pendahuluan}

Perbankan Syariah di Indonesia telah menjadi salah satu alternatif favorit masyarakat yang membutuhkan pendanaan perumahan atau Kredit Pemilikan Rumah istilah mana dalam sistem Syariah disebut dengan Pembiayaan Pemilikan Rumah. Meskipun pada Bank Syariah terdapat banyak jenis produk lainnya, mengingat bahwa untuk meningkatkan persaingan dalam hal bisnis, Perbankan Syariah juga dituntut untuk memiliki inovasi produk lain sesuai dengan kebutuhan pasar ${ }^{1}$. Jenis pembiayaan rumah syariah paling banyak digemari seiring dengan bertambahnya penduduk dan tingginya kebutuhan akan Rumah di Indonesia, yang apabila dilihat dari tujuanya maka pembiayaan pemilikan rumah ini tergolong pada jenis Kredit Konsumtif ${ }^{2}$. Kredit Konsumtif merupakan salah satu jenis Kredit dengan sistem pengembalian atau pembayaran dengan jangka waktu yang panjang, sehingga di dalamnya mengenai bunga pinjamannya pasti mengalami peningkatan, dan akan mengandung unsur riba ${ }^{3}$.

Adanya unsur ketidak pastian pada Bank dengan sistem Konvensional dalam hal Bunga, pemahaman bunga yang dikategorikan sebagai Riba adalah hal yang penting, Riba berarti bertambah dan merupakan tambahan daripada modal ${ }^{4}$, hal inilah yang wajib untuk dihindari umat islam sehingga menjadi sisi

1 Hermansyah dan Jaya Miharja, Inovasi Produk Bank Syariah (Yogyakarta, Indie Book Corner, 2013), h.

2 Malayu SP Hasibuan, Dasar-Dasar Perbankan (Jakarta;Bumi Aksara, 2006), h.89.

3 M. Ma'ruf Abdullah, Hukum Perbankan dan Perkembangan Bank Syariah di Indonesia (Banjarmasin:Antara Press, 2006), h.96.

4 Abd. Shomad, Edisi Revisi Hukum Islam Penormaan Prinsip Syariah dalam Hukum Indonesia 
menguntungkan untuk Perbankan Syariah yang menggunakan sistem margin dan bagi hasil. Perbedaan dengan Bank Konvensional tentu saja berkaitan perputaran dana dan Akad Perjanjiannya, dimana dalam Bank Konvensional dikenal dengan perjanjian hutang piutang atau Pengakuan Hutang, sedangkan dalam Perbankan Syariah digunakan Akad. Istilah "akad" dalam hukum Islam disebut perjanjian dalm bahasa Indonesia atau Contract pada bahasa Inggris ${ }^{5}$, dilaksanakan berdasarkan prinsip Syariah. Menurut Undang-Undang Nomor 10 tahun 1998 tentang Perubahan atas Undang-Undang Nomor 7 tahun 1992 tentang Perbankan yaitu pada pasal 1 angka 13 menyebutkan pengertian Prinsip Syariah ${ }^{6}$ yaitu:

"Prinsip Syariah adalah aturan perjanjian berdasarkan hukum Islam antara bank dan pibak lain untukpenyimpanan dana dan atau pembiayaan kegiatan usaha, atau kegiatan lainnya yang dinyatakan sesuai dengan syariah, antara lain pembiayaan berdasarkan prinsip bagi hasil (mudharabah), pembiayaan berdasarkan prinsip penyertaan modal (musharakahl, prinsip jual beli barang dengan memperoleh keuntungan (murabahah), ataupembiayaan barang modal berdasarkan prinsipsewa murni tanpapilihan (ijarah), atau dengan adanya pilihan pemindahan kepemilikan atas barang yang disewa daripihak bank oleh pihak lain (ijarah wa iqtina)."

Akad syariah ini dirumuskan oleh Dewan Pengawas Syariah dengan Legal Departemen Bank terkait berdasarkan fatwa yang dikeluarkan Dewan Syariah Nasional (DSN) Majelis Ulama Nasional (MUI), dan jelas tidak mengandung unsur Maghrib yaitu Maisir (Spekulasi/ Judi), Gharar (Tipu Muslihat), Riba' (Bunga), Bhatil (Kejahatan) dan Risywah (Suap) serta Objek yang haram7. Sehingga bahkan dalam menjalankan fungsinya sebagai penghimpun dan penyalur dana, Bank Syariah jauh lebih selektif dibandingkan Bank Konvensional.

Secara umum Lembaga Keuangan Syariah di Indonesia diwajibkan dalam operasionalnya menjalankan prinsip syariah yang dituangkan dalam bentuk Fatwa Dewan Syariah Nasional ${ }^{8}$. Dasar Fatwa tersbeut adalah kaidah syariah salah

(Jakarta ;Kencana,2012), h. 110.

5 Ali Amin Isfandiar, Analisis Fiqh Muamalah Tentang Hybrid Contract Model dan Penerapannya pada Lembaga Keuangan Syariah. (Online). STAIN Pekalongan, Jurnal Penelitian Vol 10, No. 2 November 20113 (http://e-journal.iaianpekolongan.ac.id diakses 4 Mei 2017), h. 209.

6 Pasal 1 angka 13 Undang Undang Nomor 7 Tahun 1992 tentang Perubahan atas Undang-Undang Nomor 7 tahun 1992 tentang Perbankan.

7 Irma Devita Purnamasari, Suswinarno, Kiat Kiat Cerdas,Mudah dan Bijak Memahami Masalah Akad Syariah (Bandung: Kaifa, 2011), h. 3-5.

8 Siti Hamidah dan Prayudo Eri Yandono, Akad Pembiayaan Mudharabah menurut pemahaman Nasabah Baitul Maal Wat Tamwil di Tongas Probolinggo, Fakultas Hukum Universitas Brawijaya Malang, (Online) Jurnal Jurisdictie Vol 7, No. 2, 2016, (//:http.www.e-journal.uin-malang.ac.id diakses 31 Juli 2017). 
satu contohya mengenai Objek Akad yang merupakan salah satu Rukun Akad diantaranya bahwa harus ada kejelasan objek yang diperjanjikan, bahwa pemilik objek haruslah orang yang secara sempurna memiliki serta berhak atas objek tersebut, dan kemudian objek tersebut haruslah sesuai dengan prinsip syariah (masyru') karena hal ini berkaitan erat dengan unsur Haram yang akan menghilangkan Asas Maslahab (Kemaslahatan) pada suatu perjanjian (Akad). Berdasarkan ajaran fiqh, haram dikategorikan menjadi 2 hal yaitu Haram karena zatnya (Haram Li Dzatihi) dan Haram karena selain zatnya (Haram Li Gharihi) ${ }^{9}$. Mengingat pentingnya unsur tersebut diperlukan pengawasan khusus akan pelaksanaan prisip syariah, Pemerintah mendukung melalui pengakuan terhadap kekuatan mengikat sebuah Fatwa yang dikeluarkan Dewan Syariah Nasional. Fatwa yang dibuat oleh Dewan Syariah Nasional dilegitimasi oleh Peraturan Bank Indonesia Nomor 23/34/1999 yang menyebutkan bahwa Bank Syariah dalam operasionalnya wajib memerhatikan fatwa yang dibuat Dewan Syariah Nasional dan tidak diperbolehkan melakukan kegiatan tanpa didasari Fatwa.

Pada Jenis Pembiayaan Property terdapat Produk Kepemilikan Rumah Syariah dan umumnya menggunakan akad Jual beli ( $\left.B a^{\prime} i\right)$ dengan Bentuk $A k a d$ Murabahah maupun Istishna' hingga dalam bentuk Sewa dengan menggunakan Hybrid Contract atau penggabungan dua akad yaitu akad Musyarakah Mutanaqisah dan Akad Ijarah. Akad Bank Syariah baik menggunakan prinsip apapun merupakan visualisasi hubungan hukum antara para pihak yang melakukan perjanjian sehingga berisi hak, kewajiban, dan tanggungn jawab apabila terdapat resiko dikemudian hari saat pembiayaan berjalan hingga cara pelunasan ${ }^{10}$. Namun umumnya produk hunian syariah atau kepemilikan rumah pada Bank Syariah menggunakan akad Murabahah yang lebih mudah dengan konsep Jual Beli disertai akad Wakalah.

Perbedaan lain terlihat saat dicermati esensi pengakhiran Kredit pada dua jenis sistem perbankan tersebut, pada Perbankan yang menggunakan sistem Syariah, sebagaimana dasar yang digunakan yaitu dari Al Quran dan Hadits salah satunya "mengulur ulur waktu pembayaran hutang bagi yang mampu adalah kezhaliman(Hadits Bukhari Muslim)" maka berdasarkan hadits tersebut diketahui bahwa seseorang yang berhutang wajib untuk segera melunasi hutang yang dimiliki apabila telah mampu, artinya sebaiknya seseorang tidak berhutang. Berawal dari sunnah tersebut, Bank dalam Pembiayaan Pemilikan Rumah yang menggunakan Akad Murabahah sehingga ia bertindak sebagai penjual dengan margin keuntungan yang telah dihitung di awal dan menjadi total hutang, ketika pada pertengahan masa

9 Burhanuddin.S, Hukum Kontrak Syariah (Yogyakarta:BPFE, 2009), h.15.

10 Muhammad Daud Ali, Hukum Islam (Pengantar Ilmu Hukum dan Tata Hukum Islam di Indonesia) (Jakarta:Raja Grafindo Persada, 2007), h. 13. 
hutang seseorang berniat untuk melunasi hutangnya tersebut maka berdasarkan prinsip syariah, Bank selaku Penjual tidak diperbolehkan untuk menghalangi niat tersebut, bahkan Bank dapat memberikan potongan hutang atau yang disebut muqasah saat pelunasan. Praktiknya, Nasabah atau Debitur yang mengajukan pelunasan dipercepat atas Pembiayaan di Bank Syariah, dibebani ketentuanketentuan yang terkesan menghambat proses pelunasan dipercepat.

Dewan Syariah Nasional melalui Fatwa nomor 23/2002 tentang Potongan Pelunasan dalam Murabahah menyebutkan bahwa Bank dibolehkan untuk memberikan potongan atas total hutang Murabahah dari Nasabah yang melakukan pelunasan dipercepat dengan syarat tidak boleh diperjanjikan dalam akad. Akan tetapi dalam beberapa Bank Syariah, penulis menemukan adanya perbedaan klausula pelunasan dipercepat khusus nya mengenai potongan pelunasan harga dalam akad murabahah yang menjadi tanda bahwa terdapat perbedaan penafsiran antara Bank Syariah sebagai bentuk implementasi dari fatwa yang dikeluarkan Dewan Syariah Nasional tersebut. Bank Syariah menjalankan kegiatannya beradasarkan prinsip syariah akan tetapi memiliki perbedaan dalam penggunakan akad, sehingga penulis menjadikan hal ini sebagai permasalahan yang diperlukan untuk diteliti lebih lanjut, terlebih juga mengenai kewenangan sanksi serta pengawasan dari Dewan Syariah Nasional sebagai lembaga pembentuk Fatwa dalam hal adanya perbedaan penafsiran bank saat mengimplementasikan fatwa yang dbuat dan upaya yang dilakukan sebagai bentuk penegakan hukum atas fatwa nomor 23 tahun 2002. Berdasarkan pendahuluan tersebut diatas penulis akan merumuskan dan menganalisis perbedaan penafsiran klausula potongan pelunasan dipercepat pada Akad Murabahah yang digunakan oleh Bank Syariah sebagai implementasi dari Fatwa Dewan Syariah Nasional nomor 23/2002 tentang potongan pelunasan dalam Murabahah dan bentuk sanksi serta pengawasan Dewan Syariah Nasional atas pencantuman klausula tersebut pada Akad Murabahah. Penulis juga akan mengkaji upaya upaya yang dilakukan Dewan Syariah Nasional apabila terdapat pelanggaran terhadap fatwa khususnya dalam fatwa nomor 23/2002 tentang potongan pelunasan dalam Murabahah.

\section{Metode Penelitian}

Penelitian merupakan penelitian hukum empiris karena penelitian ini fokus pada data dan observasi di lapangan yang kemudian didukung dengan studi kepustakaan dengan pendekatan penelitian Yuridis Sosiologis. Bahan hukum yang digunakan dalam penelitian ini menggunakan bahan hukum primer, sekunder dan tersier yang diperoleh dari dokumentasi dan studi kepustakaan. Untuk menganalisis 
penelitian ini menggunakan teknik deskriptif kualitatif dengan didukung metode purposive sampling.

Penelitian ini menggunakan 4 (empat) kerangka teoritik yang digunakan sebagai pisau analisis ketiga rumusan masalah. Untuk rumusan masalah pertama menggunakan Teori Perjanjian, untuk rumusan masalah kedua menggunakan Teori Kepastian Hukum dan Teori Kewenangan dimana untuk Teori Kewenangan juga digunakan untuk menganalisa permasalahan ketiga bersama dengan teori Efektivitas Penegakan Hukum.

\section{Pembahasan}

a. Perbedaan penafsiran klausula potongan pelunasan dipercepat Akad Murabahah Bank Syariah dalam implementasi Fatwa Dewan Syariah Nasional nomor 23/2002 tentang Potongan Pelunasan dalam Murabahah.

Penelitian ini dilakukan pada dua Bank Syariah yang banyak menangani Pembiayaan Pemilikan Rumah, yaitu Bank Muamalat dan Bank Syariah Mandiri, dimana Bank Muamalat dalam penelitian ini mewakili Bank Syariah yang didirikan tanpa menginduk pada Bank Konvensional sebagaimana halnya dengan Bank Syariah lain, sekaligus merupakan Bank pertama di Indonesia yang menjalankan kegiatan operasionalnya menggunakan prinsip Syariah. Bank Muamalat dalam praktiknya, tidak hanya menggunakan Akad Murabahah untuk pemilikan rumah akan tetapi juga menggunakan Akad Musyarakah Mutanaqisah dan Akad Ijarah yang merupakan salah satu jenis Hybrid Contract dimana sistem nya adalah syirkah dan pembayaran disebut ujrah (sewa) ${ }^{11}$, berbeda dengan Murabahah yang merupakan jenis Jual Beli disertai margin atau keuntungan Bank. Hasil pengamatan penulis dan wawancara pada kedua Pihak Bank Syariah menemukan bahwa untuk proses pengajuan pembiayaan pemilikan rumah baik pada Bank Syariah Mandiri maupun Bank Muamalat relatif sama, namun hanya berbeda istilah divisi. Kedua bank juga menghindari nasabah dengan sumber pengembalian tidak tetap, selain dikarenakan resiko pendapatan yang tidak tentu berpengaruh pada kelancaran pembayaran dan juga proses analisa pembiayaan ${ }^{12}$. Berikut bagan prosedur pelaksanaan pembiayaan pemilikan rumah pada Bank Syariah :

11 David Novan Setyawan, Upaya Bank Syariah Pada Penyaluran Kepemilikan Rumah Syariah dengan Akad Musyarakah Wal Ijarah Al Muntahia Bittamlik Dalam Hal terjadi Ingkar Janji Studi di Bank Muamalat Indonesia Malang, (Online) Fakultas Hukum Universitas Brawijaya, Jurnal Hukum, 2015, (http://hukum.studentjournal.ub.ac.id/ diakses 10 Juli 2017).

12 Hasil wawancara dengan Ibu Intan Meliyar Hati selaku Legal Retail Financing Center Bank Muamalat pada tanggal 16 Juli 2017. 
Bagan 1. Prosedur Pengajuan Pembiayaan Pemilikan Rumah Bank Syariah

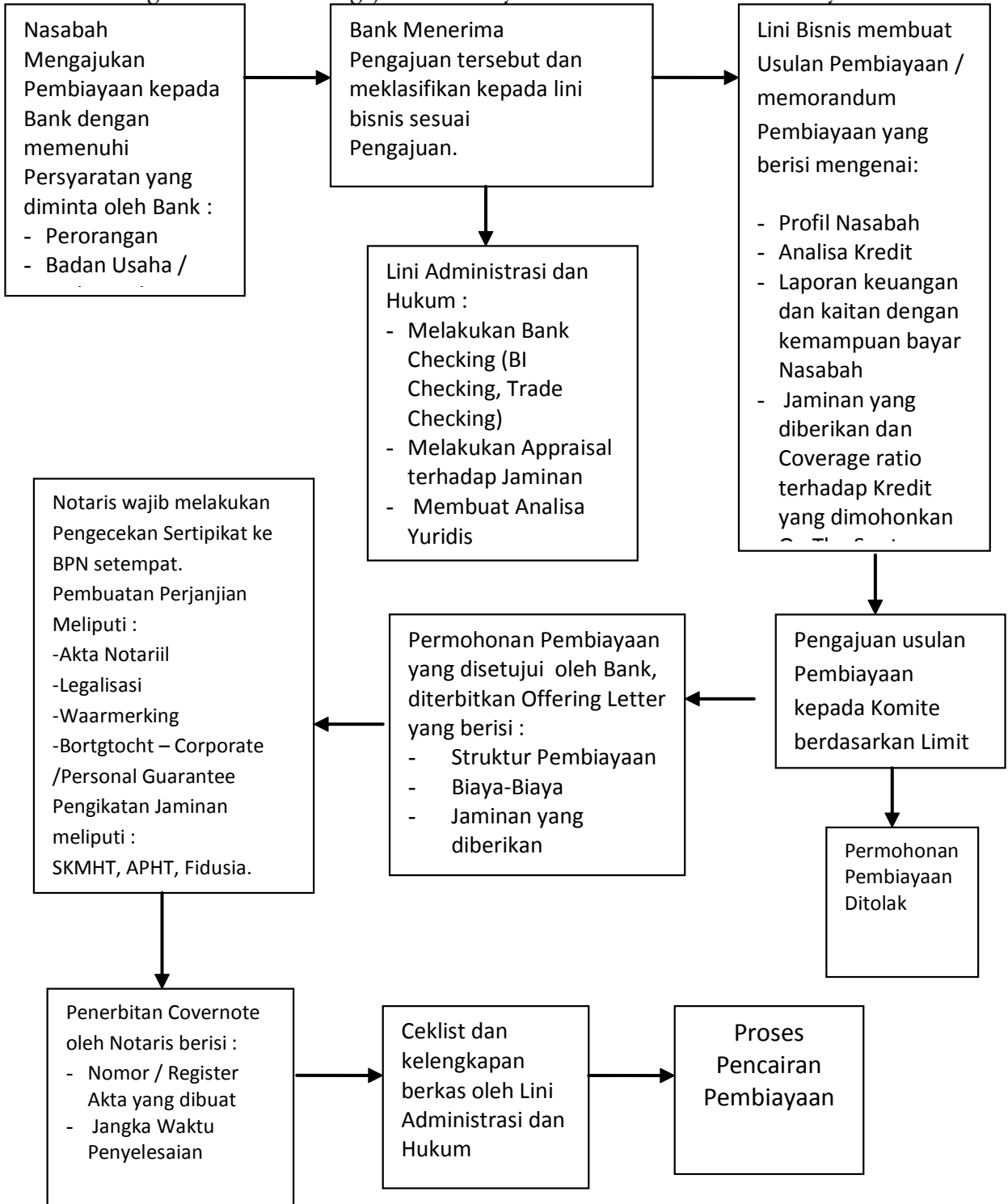

Sumber: Kreasi Penulis.

Kedua Bank sebagai Lembaga Keuangan yang menggunakan dasar syariah pada setiap perjanjian baku pembiayaannya memiliki banyak perbedaan mengenai klasula akad. Penelitian ini membahas mengenai perbedaan klausula potongan harga yang diberikan saat pelunasan dipercepat pada Akad Murabahah pembiayaan 
pemilikan rumah pada Bank Syariah tersebut yang mana ketentuan mengenai potongan harga telah diatur oleh Fatwa Dewan Syariah Nasional nomor 23/2002 tentang potongan dalam pelunasan Murabahah. Potongan atau diskon sat pelunasan Murabahah baik itu tepat waktu atau sebelum jatuh tempo, adalah hak dari Bank sebagai penjual atas pertimbangan tertentu dari pihak Bank ${ }^{13}$.

Sebagaimana Asas Kebebasan Berkontrak yang berlaku dalam Teori Hukum Perjanjian sesuai dengan Pasal 1338 KUH Perdata bahwa Para pihak bebas untuk saling memperjanjikan hal selama tidak bertentangan dengan undang-undang dan kesusilaan dan perjanjian tersebut berlaku mengikat sebagaimana undang undang bagi pihak yang membuatnya, maka sebagai akibat hukum daripada asas ini Bank sebagai Lembaga Keuangan Syariah yang menggunakan Akad Murabahah dalam kegiatan operasionalnya memiliki draft akad Murabahah yang berbeda pada satu Bank dengan Bank lainnya. Perbedaan ini merupakan salah satu hasil penafsiran Perbankan Syariah pada Fatwa yang dikeluarkan oleh Dewan Syariah Nasional dimana ketentuan yang dikeluarkan tidak bersifat mengikat dalam hal ini Pelaku Ekonomi Syariah Baik Bank maupun Nasabahnya melainkan hanya menjadi pedoman bagi para pihak. Berikut klausula pelunasan dipercepat pada kedua Bank dibandingkan dengan Fatwa Dewan Syariah Nasional nomor 23/2002 :

13 Yenti Afrida. Aplikasi Penetapan Diskon Dalam Pelunasan Murabahah di Perbankan Syariah. Mizani. (Online) Volume 25 Fakultas Ekonomi dan Bisnis Islam IAIN Imam Bojol Padang, Mizani Volume 25, No. 1, (http://ejournal.iainbengkulu.ac.id diakses 04 Juni 2017). 


\begin{tabular}{|c|c|c|}
\hline $\begin{array}{l}\text { Fatwa Dewan Syariah } \\
\text { Nasional Nomor } \\
23 / 2002\end{array}$ & $\begin{array}{l}\text { AkadPembiayaan Murabahah } \\
\text { Bank Muamalat }\end{array}$ & $\begin{array}{l}\text { Akad Pembiayaan Untuk } \\
\text { Pengadaan Rumah } \\
\text { Berdasarkan Prinsip } \\
\text { Murabahah } \\
\text { Bank Syariah Mandiri }\end{array}$ \\
\hline $\begin{array}{l}\text { "Pertama, jika nasabah } \\
\text { d a la m tra n saks i } \\
\text { murabahah melakukan } \\
\text { pelunasan pembayaran } \\
\text { tepat waktu atau lebih } \\
\text { cepat dari waktu yang } \\
\text { telah disepakati, LKS } \\
\text { boleh memberikan } \\
\text { p o t o n g a n d a r i } \\
\text { kewajiban pembayaran } \\
\text { tersebut dengan syarat } \\
\text { tidak diperjanjikan } \\
\text { didalam akad, Kedua, } \\
\text { b e s a p o to n ga n } \\
\text { sebagaimanadimaksud } \\
\text { di atas diserahkan } \\
\text { kepada kebijakan dan } \\
\text { pertimbangan LKS" }\end{array}$ & $\begin{array}{l}\text { Pasal } 17 \text { angka } 4 \\
\text { "Dalam hal terjadi pelunasan } \\
\text { dipercepat sebagaimana } \\
\text { dimaksud dalam ayat } 1 . b \text {, } \\
\text { Pasal ini Nasabah wajib } \\
\text { membayar pelunasan sebesar } \\
\text { sisa Utang Murabahah yang } \\
\text { menjadi kewajiban Nasabah } \\
\text { namun demikian Bankdapat } \\
\text { memberikan muqosah/ } \\
\text { potongan harga atas sisa } \\
\text { utang Murabahah tersebut } \\
\text { yangbesarnya sesuai dengan } \\
\text { kebijakan Bank pada saat } \\
\text { pelunasan" }\end{array}$ & $\begin{array}{l}\text { Pasal } 7 \text { angka } 5 \\
\text { "Nasabahdapatmengajukan } \\
\text { permohonan pembayaran } \\
\text { yang dipercepat sebelum } \\
\text { tanggal jatuh tempo yang } \\
\text { telahditentukandalamakad } \\
\text { sepanjang Nasabah telah } \\
\text { memberitahukan secara } \\
\text { tertulis terlebih dahulu } \\
\text { kepada Bankselambat- } \\
\text { lambatnya } 14 \text { (empatbelas) } \\
\text { hari kerja sebelum tanggal } \\
\text { pelunasan dipercepat } \\
\text { tersebut dengan ketentuan } \\
\text { dan syarat yang ditentukan } \\
\text { oleh Bank. Jika bank } \\
\text { menyetujui secara tertulis } \\
\text { bahwa Nasabah melunasi } \\
\text { pembiayaan kepada Bank } \\
\text { sebelum tanggal jatuh } \\
\text { tempo maka Nasabah } \\
\text { harus membayar jumlah } \\
\text { kewajban yang besarnya } \\
\text { ditentukan Bank." }\end{array}$ \\
\hline
\end{tabular}

Dalam menafsirkan Fatwa Dewan Syariah Nasional, Bank Muamalat dan Bank Syariah Mandiri menggunakan metode penafsiran Gramatikal akan tetapi berbeda satu sama lain pada praktiknya. Bank Muamalat menafsirkan bahwa jumlah potongan harga tidak boleh diperjanjikan bahkan dalam ketentuan internal namun dalam klausula pelunasan dipercepat pada Akad Murabahah dibuat sebagaimana bunyi ketentuan dalam Fatwa nomor 23/2002. Akibat penafsiran yang dilakukan 
oleh Bank Muamalat ini adalah prosedur bertingkat yang harus dilakukan saat adanya pengajuan pelunasan dipercepat. Cabang harus membuat memorandum tertulis kepada divisi terkait sekaligus Direksi di Kantor Pusat Bank Muamalat mengenai besaran potongan yang akan diberikan kepada Nasabah, sehingga prosedur ini cukup menghabiskan banyak waktu. Pada tahun 2016, jumlah potongan rata-rata yang diberikan Bank Muamalat atas pelunasan dipercepat setiap bulannya adalah sekitar 2 hingga 5 kali margin ditambah dengan sisa pokok ${ }^{14}$.

Bank Syariah Mandiri sebaliknya tidak menyebutkan adanya potongan harga baik itu jumlah maupun kemungkinan ada nya potongan harga saat pelunasan dalam Akad Murabahah nya, akan tetapi mengatur besaran potongan harga tersebut dalam Ketentuan Internal yang disebut dengan standar operasional prosedur yaitu sebesar 1 kali margin ditambah sisa pokok ${ }^{15}$. Adanya ketentuan internal mengenai potongan harga dalam Murabahah di Bank Syariah Mandiri ini tentunya lebih menguntungkan dari sisi efektivitas waktu bagi Cabang dalam memproses pengajuan pelunasan dipercepat disertai potongan.

Hal utama yang perlu ditekankan bahwa kedua Bank menyebutkan bahwa setiap terjadi pelunasan dipercepat, Bank selalu memberikan potongan, berapapun besarannya. Pemberian potongan tersebut didasari beberapa faktor yang paling berpengaruh yaitu :

1. Faktor Kelancaran Pembiayaan Nasabah

Bank cenderung melihat dari prospek Nasabah kedepannya bagi keuntungan produk lainnya pada Bank itu.

Apabila keadaan pembiayaan Nasabah tergolong bermasalah atau macet Bank bisa saja mengeluarkan kebijakan pengurangan siginifikan terhadap tunggak atau bahkan menghapus tunggakan akan tetapi bila pelunasan itu dilakukan oleh Kreditor lain, maka Bank cenderung memberikan sedikit potongan. Hal ini sesuai dengan ketentuan yang dibuat Dewan Syariah Nasional melalui Fatwa Nomor 46/DSN-MUI/II/2005 tentang Potongan Tagihan Murabahah (Khasim Fi Al Murabahah) yang menyebutkan bahwa ${ }^{16}$ :

"Pertama, LKS boleh memberikan potongan dari total kewajiban pembayaran kepada Nasabah dalam transaksi Akad Murabahahyang telah melakukan kewajiban pembayaran cicilannya dengan tepat waktu dan Nasabah yang mengalami penurunan kemampuan pembayaran, Kedua, Besaran potongan sebagaimana dimaksud diatas diserabkan pada kebijakan LKS, Ketiga, Pemberian Potongan tidak boleh diperjanjikan dalam Akad"

14 Wawancara dengan Ibu Intan Meliyar Hati, Legal Officer Retail Financing Center Area Jawa Bali Nusra Bank Muamalat pada tanggal 14 Juni 2017.

15 Standar Prosedur Bisnis Pembiayaan Konsumer Bank Syariah Mandiri tahun 2016

16 Fatwa Dewan Syariah Nasional Nomor 46/DSN-MUI/II/2005 tentang Potongan Tagihan Murabahah (Khasim Fi Al Murabahah). 
Apabila Nasabah dengan kategori pembiayaan lancar, dan dikemudian hari memiliki prospek baik sebagai Nasabah Referral atas produk lainnya, maka Bank melalui unit pengajuan akan membuat memorandum penyimpangan dan permohonan pemberian muqasah lebih besar daripada ketentuan yang ditetapkan Direksi. Umumnya Direksi membuat Standar operasional prosedur sebagai panduannya akan tetapi pada praktiknya akan diserahkan kepada kebijakan cabang masing-masing sehingga disini berlaku Lex specialis derogate lex gineralis dimana Standar operasional merupakan peraturan umum yang dapat dikesampingkan dengan adanya peraturan khusus dari cabang selama peraturan itu tidak bertentangan dengan standar operasional prosedur.

\section{Faktor Keadaan Perusahaan}

Dalam pembuatan ketentuan internal mengenai Muqasah yang diberikan saat pelunasan Murabahah, Bank melihat berbagai aspek perusahaannya baik dari segi laba yang telah didapat maupun tingkat pembiayaan bermasalah saat itu. Sehingga ketentuan ini memang dapat berubah sewaktu-waktu, ketika perusahaan dalam keadaan laba minimal maka tentunya Bank membuat ketentuan potongan sedikit dengan tujuan tetap mendapatkan laba besar dari pembiayaan tersebut, dapat juga berupa ketentuan larangan pelunasan dipercepat selama jangka waktu tertentu pembiayaan.

Berdasarkan pada teori Perjanjian sebagaimana tertulis dalam Pasal 1338 yang disebut sebagai asas kebebasan berkontrak, dikategorikan sebagai peraturan yang sifatnya aanvullen, mengatur dan boleh disimpangisepanjang tidak bertentangan dengan ketentuan perundang undangan atau disebut dalam pasal $1320 \mathrm{KUH}$ Perdata mengenai syarat sahnya perjanjian yang menjadi awal mula terjadinya perjanjian ${ }^{17}$. Begitu pula dengan ketentuan Fatwa Dewan Syariah Nasional ini yang membebaskan para pihak untuk melakukan penafsiran baik itu secara gramatikal dan berdasarkan dengan kebiasaan. Penulis mempersamakan KUH Perdata sebagai ketentuan umum yang berlaku dalam Perbankan Syariah, sedangkan prinsip syariah itu sendiri merupakan suatu ketentuan khusus yang harus dipenuhi dalam transaksi Syariah. Apabila ketentuan syariah tidak mengatur maka berlaku ketentuan dari Hukum Perjanjian sebagaimana diatur dalam KUH Perdata sebagai lex gineralis. Namun, untuk legitimasi Fatwa oleh Peraturan Bank Indonesia, pemaknaan fatwa itu sendiri menjadi sangat penting sebelum dibuat Peraturan nya oleh Bank Indonesia ${ }^{18}$. Sehingga pembuatan fatwa seharusnya lebih mudah dipahami agar tidak terjadi multitafsir dalam implementasinya.

17 Komariah, Hukum Perdata (Malang: UMM Press, 2005), h. 168.

18 Jundiani, Pengantar Hukum Perbankan Syariah di Indonesia (Malang: UIN Malang Press, 2009), h.129. 
b. Bentuk sanksi dan pengawasan Dewan Syariah Nasional atas dicantumkannya klausula potongan pelunasan dipercepat pada Akad Bank Syariah.

Dalam Perbankan Syariah, Hukum Perjanjian yang diatur KUH Perdata berlaku secara umum apabila secara syariah tidak memiliki pengaturan khusus, termasuk fatwa yang dibuat oleh Dewan Syariah Nasional akan berlaku mengikat bagi Lembaga Keuangan Syariah meskipun belum dilegitimasi dalam bentuk peraturan Bank Indonesia ${ }^{19}$. Kepatuhan pelaku bisnis syariah diserahkan kewenangannya kepada Majelis Ulama Indonesia melalui Dewan Syariah Nasional dengan bentuk adanya Dewan Pengawas Syariah yang harus ada pada setiap struktur organisasi Bank Umum maupun Unit Usaha yang menggunakan prinsip syariah ${ }^{20}$. Berdasarkan teori kewenangan yang diutarakan oleh Philipus M. Hadjon terdapat dua jenis kewenangan yaitu Atribusi dan Delegasi ${ }^{21}$, kedudukan Dewan Syariah Nasional pada tataran kewenangan guna pemberian sanksi dan pengawasan terhadap jalannya ekonomi syariah berada pada poin Atribusi.

Kewenangan Atribusi pada Dewan Syariah Nasional bermula dari dibentuknya Undang-Undang Nomor 21 tahun 2008 tentang Perbankan Syariah yang pada Bagian Ketiga Pasal 32 yang menyebutkan mengenai kewajiban pembentukan Dewan Pengawas Syariah pada setiap Perbankan Syariah, selanjutnya menyebutkan bahwa kewenangan pembentukan Dewan Pengawas Syariah melalui Rapat Umum Pemegang Saham dan Rekomendasi dari Majelis Ulama Indonesia dalam hal ini adalah Dewan Syariah Nasional serta akan diatur lebih lanjut dalam Peraturan Bank Indonesia.

Selanjutnya dalam Peraturan Bank Indonesia nomor 11/15/PBI/2009 tentang Perubahan Kegiatan Usaha Bank Konvensional Menjadi Bank Syariah Kedudukan Dewan Syariah Nasional jelas tercantum dalam Ketentuan Umum pasal 1 angka 7 , yang menyebutkan bahwa Dewan Syariah Nasional adalah sebuah Lembaga yang mengeluarkan fatwa sesuai prinsip hukum islam yang digunakan oleh kegiatan Perbankan, selanjutnya dalam kewenangan lainnya, Dewang Pengawas Syariah yang meskipun diatur secara langsung oleh Undang-Undang Nomor 21 Tahun 2008 tentang Perbankan Syariah tetapi terdapat ketentuan lanjutan dalam Pasal 31,32, 33 Peraturan Bank Indonesia dimana disebutkan bahwa penetapan anggota Dewan Pengawas Syariah diajukan oleh Bank dalam hal ini adalah Rapat Umum Pemegang Saham, kemudian permohonan persetujuan kepada Bank Indonesia

19 Sutan Remy Sjahdeiny, Perbankan Syariah, Produk Produk dan aspek aspek hukumnya (Jakarta: Kencana, 2014), h. 97.

20 Warkum Sumitro, Hukum Islam ditengah Dinamika Sosial Politik di Indonesia (Malang:Setara Press, 2016), h. 202.

21 Ridwan HR, Hukum Adminsitrasi Negara (Jakarta: Rajawali Press, 2011), h. 104. 
dan dilakukan penetapan oleh Dewan Syariah Nasional yang merupakan bagian dari Majelis Ulama Indonesia bidang pelaksanaan Ekonomi Islam. Berdasarkan tugas dan wewenang dalam pedoman dasar tersebut diatas, peraturan yang dibuat oleh Dewan Syariah Nasional bersifat aanvullen dan karena keberadaan Dewan yang berada diluar struktur dari Bank Sentral membuat lembaga ini menjadi lebih independen, kredibel dan diakui dalam hal kompetensi pembuatan fatwa, akan tetapi karena sifat Dewan yang dalam struktur keanggotaanya belum memiliki pembagian unit yang spesifik mengenasi urusan yang dikerjakan seperti ekonomi makro, perbankan syariah, reksadana maupun asuransi sehingga kemampuan penyelesaian masalah menjadi kurang efektif karena ketidak responsifan Dewan ${ }^{22}$, sehingga untuk mengoptimalisasikan kinerja Dewan Syariah Nasional dan lebih Kompleksnya permasalahan keuangan syariah yang muncul dalam praktik, hendaknya dibentuk unit unit khusus dalam keanggotaan dan struktur Dewan Syariah Nasional.

Fungsi Dewan Syariah Nasional berkaitan erat dengan lingkup Pengawasan yang dalam praktiknya bersinergi dengan Bank Indonesia selaku regulator Perbankan di Indonesia, dan ditambah dengan lembaga baru yang menjalankan fungsi pengawasan serta pembinaan lembaga keuangan menggantikan Bank Indonesia yaitu Otoritas Jasa Keuangan (OJK) sebagaimana tercantum dalam Undang Undang Nomor 21 tahun 2011 tentang Otoritas Jasa Keuangan. Sejak adanya Otoritas Jasa Keuangan, menjadikan Bank Indonesia hanya menjalankan fungsi Moneter dan ekonomi makro sedangkan fungsi pengawasan terhadap lembaga keuangan baik berbentuk Bank maupun non Bank seperti Asuransi, reksadana, pensiun dan lembaga pembiayaan diserahkan kepada Otoritas Jasa Keuangan.

Peran Dewan Syariah Nasional sebagai pembuat fatwa yang menjadi pedoman pelaku ekonomi syariah dalam melakukan kegiatannya sangat penting dalam mewujudkan Kepastian Hukum dalam masyarakat khususnya pengguna jasa lembaga keuangan syariah termasuk perbankan. Penulis berpendapat bahwa unsur Kepastian Hukum dalam peran dan fungsi Dewan Syariah Nasional terpusat pada pembuatan Fatwa. Dimana Fatwa memiliki kekuatan untuk memberikan Kepastian hukum bagi para pihak meskipun Fatwa yang merupakan karakteristik dari produk syariah, bersifat kasuistik, karena ia adalah bentuk respon atau jawaban terhadap pertanyaan yang diajukan oleh peminta fatwa ${ }^{23}$.

22 Ascarya, Akad \& Produk Bank Syariah (Jakarta:Rajawali Press, 2011), h.207.

23 Bahrul Ulum Annafi, Formalisasi Syariah (Penormaan dan Karakteristik Prinsip Syariah dalam Hukum Nasional Indonesia), (Online), Magister Ilmu Hukum Fakultas Hukum Universitas Brawijaya, Jurnal Hukum, 2014, (http://www.hukum.studentjournal.ub.ac. id diakses 14 April 2017). 
Menurut Lord Fuller terdapat beberapa unsure penentu kepastian hukum, dan atas hal tersebut maka beberapa unsur dari fatwa telah memenuhi seperti bahwa fatwa dibentuk berdasarkan penelitian dan dikaji secara mendalam dan sistematis oleh suatu lembaga yang berkompeten dibidang nya dan kemudian fatwa tersebut dapat diakses secara mudah oleh masyarakat umum. Kepastian hukum mengenai kedudukan fatwa Dewan Syariah Nasional dengan demikian telah terbukti memberikan kepastian bagi para pelaku ekonomi syariah akan tetapi adanya perbedaan penafsiran pada implementasi Fatwa dalam pembuatan akad pembiayaan yang digunakan oleh Bank membuktikan pula bahwa Fatwa hendaknya dibuat lebih jelas dan dengan rumusan yang lebih mudah dipahami sehingga tidak menimbulkan penafsiran berbeda bagi para pihaknya.

Kepastian hukum fatwa tersebut menurut penulis belum terasa sempurna dikarenakan kekuatan fatwa yang tidak bersifat memaksa/dwingen sebagaimana kewenangan pemberian sanksi oleh lembaga pengatur Perbankan Syariah di Malaysia. Mengacu kepada pedoman dasar Dewan Syariah Nasional tidak menyebutkan kewenangan Dewan Syariah Nasional dalam menjatuhkan sanksi kepada lembaga keuangan yang melakukan pelanggaran terhadap fatwa yang dikeluarkan, melainkan hanya memberikan peringatan kepada lembaga keuangan syariah yang melakukan pelanggaran dan kemudian mengusulkan kepada instansi yang berwenang dalam hal ini adalah Bank Indonesia untuk melanjutkan permasalahan ini apabila peringatan tidak dipedulikan.

Akan tetapi dirunut dari segi syariah compliance, Bank Indonesia dan Otoritas Jasa Keuangan dibolehkan untuk mengajukan pembuatan fatwa kepada Dewan Syariah Nasional apabila menganggap adanya permasalahan pelanggaran syariah compliance ${ }^{24}$. Tidak hanya Bank Indonesia tetapi, Dewan Syariah Nasional juga dibolehkan untuk melakukan inisiatif dalam pengawasan Bank Syariah dan Dewan Pengawas Syariah nya dengan cara melaporkan pelanggaran tersebut kepada instansi terkait yaitu Otoritas Jasa Keuangan. Otoritas ini kemudian harus melakukan tindakan pemeriksaan, dan kemudian apabila terbukti barulah akan dijatuhi sanski sesuai dengan peraturan yang berlaku.

c. Upaya Dewan Syariah Nasional dalam rangka penegakan hukum atas implementasi Fatwa Dewan Syariah Nasional Nomor 23/DSN-MUI/III/2002 tentang Potongan dalam Pelunasan Murabahah.

Upaya penegakan hukum atas implementasi Fatwa Dewan Syariah Nasional Nomor 23/DSN/MUI/III/2002 tentang Potongan dalam 24 Wirdyaningsih, Bank dan Asuransi Islam di Indonesia (Jakarta: Kencana, 2005), h. 91. 
pelunasan Murabahah dapat diidentifikasi melalui dua cara yaitu :

1. Optimalisasi Fungsi DewanPengawas Syariah Dalam Perbankan Syariah

Dewan ini bertugas untuk melakukan kegiatan pengawasan pada operasional Bank agar sesuai dengan kaidah syariah sekaligus memberikan masukan kepada direksi tentang kebijakan yang akan dijalankan. Selain itu, menjadi pembeda bank syariah dengan bank konvensional menjadikan peran Dewan Pengawas Syariah sangat vital pada kegiatan operasional Bank Syariah, seperti menjadi mediator antara Bank dengan lembaga terkait termasuk pemerintahan dalam hal pengajuan pengembangan produk dan jasa perbankan syariah juga setelah dibentuk Dewan Syariah Nasional, maka Dewan Pengawas Syariah menjadi kepanjangan tangan daripada DSN dan wajib untuk untuk membuat laporan kegiatan Perbankan tersebut kepada DSN minimal satu tahun sekalii ${ }^{25}$. Praktiknya banyak Bank dalam pembuatan Akad Pembiayaan maupun ketentuan lain tidak melibatkan Dewan Pengawas Syariah, melainkan hanya internal divisi terkait saja. Optimalisasi peran Dewan Pengawas Syariah yang dimaksud disini adalah juga melebarkan fungsi Dewan Pengawas itu sendiri untuk kebijakan internal perusahaan. Misalnya dalam hal pemberian muqasah yang walaupun merupakan hak dari Bank akan tetapi pemberian sedikit muqasah dan membuat Nasabah merasa terbebani tentu nya tidak sesuai dengan asas mashlahah atau kemanfaatan Perbankan Syariah itu sendiri sehingga Dewan Pengawas dapat memberikan masukan saran kepada Direksi mengenai hal tersebut, agar tidak menyimpangi prinsip syariah.

Dewan ini dapat pula bekerjasama dengan divisi internal audit, compliance sharia dan legal divisi guna melakukan pemantauan lebih dalam terhadap tiap transaksi Bank mengingat pada kegiatan Bank terdapat pelaksana dan pemeriksa maka disini hendaknya Dewan Pengawas Syariah mampu berada pada dua sisi tersebut akan tetapi pada ketentuan yang bersifat syar'i seharusnya lebih berada di Sisi Pemeriksa sebuah Bank. Sehingga sangat diperlukan penambahan wewenang dan anggota daripada Dewan Pengawas Syariah pada sebuah Bank untuk dapat mengoptimalkan fungsinya. Optimalisasi fungsi Dewan Pengawas Syariah juga sangat mungkin dicapai melalui peningkatan independensi, integritas dan kompetensi anggota Dewan Pengawas Syariah serta kesiapan dari manajemen lembaga keuangan itu sendiri, dimana setiap akad pembiayaan yang digunakan untuk Produk Bank diharuskan untuk diverifikasi lebih dahulu oleh Dewan Pengawas Syariah. Pengawasan ini bahkan hingga produk dan akad tersebut selesai berjalan untuk mencegah adanya penyimpangan disaat Produk tersebut telah dipasarkan.

25 Mardani, Aspek Hukum Lembaga Keuangan Syariah di Indonesia (Jakarta: Kencana, 2015), h.74. 


\section{Standarisasi Akad Pembiayaan Perbankan Syariah}

Banyaknya perbedaan mengenai konsep dan standar baku akad perbankan syariah membuat beberapa pihak memunculkan ide untuk melakukan standarisasi akad atau perjanjian perjanjian baku Perbankan Syariah. Misalnya pada Akad Murabahah, Musyarakah, Mudharabah, berisi ketetuan yang sama antara Bank Syariah satu dengan lainnya. Sedangkan apabila Bank ingin membuat suatu ketentuan yang sifatnya khusus untuk nasabah tertentu, maka Bank dapat mencantumkannya dalam Surat Persetujuan Pembiayaan yang diterbitkan sebelum Pengikatan Pembiayaan berlangsung. Surat Persetujuan pembiayaan ini juga bersifat lebih fleksibel dalam hal tawar menawar persyaratan oleh Nasabah kepada Bank sehingga lebih mungkin mengakomodir kepentingan kedua belah pihak. Tentunya dalam poin ini yang berwenang untuk melakukan standarisasi akad adalah pihak yang berkompeten dalam ekonomi syariah di Indonesia yaitu Dewan Syariah Nasional yang kemudian dilegitimasi oleh Regulator Perbankan di Indonesia yaitu Otoritas Jasa Keuangan dan Bank Indonesia. Sutan Remy Sjadeiny merupakan salah satu pakar yang menyarakan pembentukan standarisasi perjajian Perbankan Syariah yang menurutnya dengan adanya standarisasi tersebut akan mewujudkan hal sebagai berikut ${ }^{26}$ :

1. Lingkup dan isi perjanjian pada Perbankan Syariah mengenai tiap transaksi nya tidak lagi berbeda-beda seperti saat ini.

2. Apabila perjanjian telah diseragamkan antara Bank Syariah satu dengan lainnya, maka klausula didalamnya dapat menjadi sumber informasi untuk Nasabah yang kurang memahami prinsip syariah, para pihak yang berperkara hingga menjadi acuan dari Hakim yang menangani perkara Syariah.

3. Meminimalisir pembuatan akad yang merugikan Nasabah, sebagaimana telah disebutkan diatas bahwa Akad Bank yang merupakan Standart Contract dibuat dan diverifikasi oleh Pihak Bank sendiri sehingga memungkinkan klausula klausula yang sifatnya hanya menguntungkan Bank dengan memberikan penekanan terhadap kewajiban Nasabah dan Hak Bank saja. Sehingga akad yang demikian melanggar asas kepatutan dan keadilan serta berpotensi dikemudian hari untuk dinyatakan batal demi hukum apabila berperkara di pengadilan.

Berdasarkan kepada usulan stadarisasi akad pembiayaan Bank Syariah oleh para praktisi dan akademisi, pemerintah telah berupaya pula untuk mengurangi kesenjangan perbedaan antara Akad milik bank satu dengan bank lain dalam

26 Sutan Remy Sjahdeiny, Perbankan...., h. 150-151. 
bentuk sosialisasi dan workshop workshop mengenai ekonomi islam, disamping itu juga adanya penerbitan buku pedoman standar pembiayaan oleh lembaga berwenang di bidang Perbankan Syariah dalam hal ini adalah Otoritas Jasa Keuangan. Lembaga ini melalui divisi Departemen Perbankan Syariah telah menerbitkan Standart Produk Perbankan Syariah Murabahah pada tahun 2016 yang di dalamnya terdapat Draft Standar Akad pembiayaan Murabahah. Dengan penerbitan panduan ini diharapkan kalangan Perbankan Syariah dapat melakukan perubahan terhadap draft, klausula maupun syarat syarat pada Draft akad yang digunakan pada transaksi Murabahah.

Upaya standarisasi Akad perbankan syariah merupakan salah satu bentuk mengoptimalisasikan kerja dari sebuah perangkat hukum dalam hal ini ada fatwa yang dikeluarkan oleh Dewan Syariah Nasional sehingga menjadi lebih efektif pula penegakan dari hukum dan dengan demikian tidak lagi menimbulkan perbedaan penafsiran antaran pelaku usaha ekonomi syariah di Indonesia.

\section{Simpulan}

Berdasarkan hasil penelitian diatas yang bermula dari pokok permasalahan yang penulis analisa, simpulan yang didapat oleh penulis yang pertama adalah bahwa Perbedaan penafsiran dalam implementasi Fatwa Nomor 23/2002 tentang Potongan Pelunasan pada Akad Murabahah disebabkan karena adanya perbedaan metode penafsiran yang digunakan Bank. Secara gramatikal Bank Muamalat menafsirkan bahwa Potongan pelunasan tidak boleh diperjanjikan baik itu di dalam akad maupun dalam ketentuan standar operasional perusahaan. Bank Syariah Mandiri dengan penafsiran gramatikal tidak mencantumkan klausula potongan harga dalam Akad pembiayaan Murabahah akan tetapi dengan metode penafsiran historis dan kemungkinan besarnya potensi permasalahan ini, Bank Syariah Mandiri mengatur besaran potongan harga dalam ketentuan Internal perusahaan berbentuk Standar Operasional Prosedur . Akan tetapi pemberian potongan selalu diberikan untuk Nasabah yang mengajukan pelunasan dipercepat dengan pertimbangan :

1. Keadaan Bank itu sendiri dalam hal penerimaan laba yang kemudian dituangkan dalam bentuk ketentuan internal oleh Direksi dan divisi terkait dan ketentuan ini sewaktu waktu dapat berubah.

2. Keadaan kemampuan bayar dan itikad Nasabah.

Kedua, Dewan Syariah Nasional melalui fatwa yang dikeluarkan bersifat aanvullen atau mengatur sehingga tidak memiliki cukup kewenangan untuk 
memberikan sanksi secara langsung kepada Perbankan. Melainkan bentuk sanksi yang diberikan adalah bisa berupa rekomendasi kepada regulator perbankan yaitu Otoritas Jasa Keuangan (OJK) dan Bank Indonesia atas penyimpangan yang dilakukan suatu Bank, untuk kemudian OJK dan Bank Indonesia yang akan memberikan tindak lanjut atas penyimpangan tersebut berupa sanksi administrative yang tidak menutup kemungkinan pada sanksi pidana sebagai akibat dari adanya pelanggaran dari kerahasiaan Bank. Selanjutnya simpulan terakhir mengenai upaya yang dilakukan Dewan Syariah Nasional dalam rangka penegakan Fatwa nya khususnya dalam hal ini adalah fatwa Nomor 23/2002 tentang potongan dalam pelunasan Murabahah dilakukan melalui optimalisasi peran dan fungsi Dewan Pengawas Syariah pada setiap Bank, dan upaya untuk melakukan standarisasi akad yang digunakan oleh Perbankan Syariah dalam setiap transaksinya dimana upaya ini telah berjalan melalui terbitnya Standar Produk Perbankan Syariah Murabahah oleh Otoritas Jasa Keuangan pada tahun 2016 sehingga melalui standar produk ini diharapkan dapat meminimalisir perbedaan tafsir dan pelaksanaan produk yang menggunakan akad Murabahah pada Perbankan Syariah. Sehingga dari simpulan tersebut dapat diketahui bahwa Perbankan Syariah mendapatkan ekspetasi besar dari Masyarakat karena menggunakan prinsip syariah dan diharapkan tidak merugikan merupakan beban berat, sehingga kedepannya agar lebih menyeimbangkan kepentingan perolehan keuntungan atau Laba Bank dengan tingkat kepuasan Nasabah, mengingat adanya asas kemaslahatan yang dianut agar mencapai kemanfaat untuk semua pihak, dan juga ketatnya persaingan bisnis perbankan, sehingga dalam hal pemberian muqasah agar mempertimbangkan aspek tersebut. Sedangkan Dewan Syariah Nasional, yang berdasarkan ketentuan perundang-undangan yang berlaku di Indonesia mengenai Perbankan Syariah,ketentuannya tidak bersifat memaksa, agar mendukung optimalisasi peran dan fungsi Dewan Pengawas Syariah sebagai kepanjangan tangannya di internal Perbankan Syariah.

Peran Dewan Syariah Nasional menjadi sangat vital dalam transaksi berprinsip ekonomi islam, salah satu nya dengan cara pembuatan fatwa yang lebih jelas dan disertai dengan petunjuk pelaksanaan sehingga dapat meminimalisir adanya perbedaan pendapat. Hendaknya pemerintah melalui Bank Indonesia dan Otoritas Jasa Keuangan, agar lebih membuka pintu masukan dan saran terutama dari Nasabah Bank Syariah, melakukan sosialisasi kepada khalayak umum mengenai prinsip syariah dan melakukan pengawasan lebih menyeluruh pada aspek pelayanan Nasabah mengingat banyak bank Syariah yang baru dibentuk tahun 2000 dan agar dikemudian hari dapat memungkinkan penguatan wewenang dari Dewan Syariah Nasional dan Dewan Pengawas Syariah untuk mengoptimalisasikan fungsi 
Pengawasan terhadap aspek Syariah pada lembaga keuangan agar tetap berada di koridor hukum Islam.

\section{Daftar Pustaka}

Shomad, Abd. Edisi Revisi Hukum Islam Penormaan Prinsip Syariah dalam Hukum Indonesia. Jakarta: Kencana, 2012.

Isfandiar, Ali Amin. Analisis Fiqh Muamalah Tentang Hybrid Contract Model dan Penerapannya pada Lembaga Keuangan Syariah. (Online) STAIN Pekalongan, Jurnal Penelitian Vol 10, No. 2 November 20113 (http://ejournal.iaianpekolongan.ac.id diakses 4 Mei 2017).

Ascarya. Akad dan Produk Bank Syariah. Jakarta : Raja Grafindo, 2011.

Annafi, Bahrul Ulum. Formalisasi Syariah (Penormaan dan Karakteristik Prinsip Syariah dalam Hukum Nasional Indonesia), (Online) Magister Ilmu Hukum Fakultas Hukum Universitas Brawijaya, Jurnal Hukum, 2014, (http:// www.hukum.studentjournal.ub.ac.id diakses 14 April 2017).

Burhanuddin.S. Hukum Kontrak Syariah. Yogyakarta: BPFE, 2009.

Setyawan, David Novan. Upaya Bank Syariah Pada Penyaluran Kepemilikan Rumah Syariah dengan Akad Musyarakah Wal Ijarah Al Muntahia Bittamlik Dalam Hal terjadi Ingkar Janji Studi di Bank Muamalat Indonesia Malang, (Online) Fakultas Hukum Universitas Brawijaya, Jurnal Hukum, 2015, (http:// hukum.studentjournal.ub.ac.id/ diakses 10 Juli 2017).

Hermansyah dan Jaya Miharja. Inovasi Produk Bank Syariah. Yogyakarta: Indie Book Corner, 2013.

Irma Devita Purnamasari dan Suswinarno. Kiat Kiat Cerdas, Mudah dan Bijak Memahami Masalah Akad Syariah. Bandung: Kaifa, 2011.

Jundiani. Pengantar Hukum Perbankan Syariah di Indonesia. Malang: UIN Malang Press, 2009.

Komariah. Hukum Perdata. Malang: UMM Press, 2005.

Abdullah, M. Ma'ruf. Hukum Perbankan dan Perkembangan Bank Syariah di Indonesia. Banjarmasin: Antara Press, 2006.

Hasibuan, Malayu, SP. Dasar-Dasar Perbankan. Jakarta: Bumi Aksara, 2006. 
Mardani. Aspek Hukum Lembaga Keuangan Syariah di Indonesia. Jakarta: Kencana, 2015.

Ali, Muhammad Daud. Hukum Islam (Pengantar Ilmu Hukum dan Tata Hukum Islam di Indonesia). Jakarta: Raja Grafindo Persada, 2007.

Ridwan HR. Hukum Administrasi Negara Edisi Revisi. Jakarta: Rajawali Press, 2011.

Siti Hamidah dan Prayudo Eri Yandono, Akad Pembiayaan Mudharabah menurut pemahaman Nasabah Baitul Maal Wat Tamwil di Tongas Probolinggo, (Online) Fakultas Hukum Universitas Brawijaya Malang, Jurnal Jurisdictie Vol 7, No. 2, 2016, (http://www.e-journal.uin-malang.ac.id diakses 31 Juli 2017)

Sjahdeini, Sutan Remy. Perbankan Syariah Produk-Produk dan Aspek-Aspek Hukumnya. Jakarta: Penerbit Kencana, 2014.

Sumitro, Warkum. Hukum Islam ditengah Dinamika Sosial Politik di Indonesia. Malang: Setara Press, 2016.

Wirdyaningsih dkk. Bank Dan Asuransi Islam di Indonesi. Jakarta: Kencana, 2005.

Afrida, Yenti. Aplikasi Penetapan Diskon Dalam Pelunasan Murabahah di Perbankan Syariah. Mizani. (Online) Fakultas Ekonomi dan Bisnis Islam IAIN Imam Bojol Padang, Mizani Volume 25, No. 1, (http://ejournal.iainbengkulu. ac.id diakses 04 Juni 2017) 